\title{
The RNA-Binding Protein CsrA Controls Virulence in Erwinia amylovora by Regulating RelA, RcsB, and FIhD at the Posttranscriptional Level
}

\author{
Jae Hoon Lee, Veronica Ancona, Tiyakhon Chatnaparat, Ho-wen Yang, and Youfu Zhao ${ }^{\dagger}$ \\ Department of Crop Sciences, University of Illinois at Urbana-Champaign, Urbana, IL 61801, U.S.A. \\ Accepted 29 May 2019.
}

CsrA, an RNA-binding protein, binds to target transcripts and alters their translation or stability. In Erwinia amylovora, CsrA positively regulates the expression of type III secretion system (T3SS), exopolysaccharide amylovoran, and motility. In this study, the global effect of CsrA and its noncoding small RNA (ncsRNA) $c s r B$ in $E$. amylovora was determined by RNAseq, and potential molecular mechanisms of CsrA-dependent virulence regulation were examined. Transcriptomic analyses under the T3SS-inducing condition revealed that mutation in the $c s r A$ gene led to differential expression of more than $20 \%$ of genes in the genome. Among them, T3SS genes and those required for cell growth and viability were significantly downregulated. On the other hand, the $\operatorname{csr} B$ mutant exhibited significant upregulation of most major virulence genes, suggesting an antagonistic effect of $c s r B$ on CsrA targets. Direct interaction between CsrA protein and $\operatorname{csr} B$ was further confirmed through the RNA electrophoretic mobility shift assay (REMSA). However, no direct interaction between CsrA and $h r p L$ and $h r p S$ transcripts was detected, suggesting that $\mathrm{HrpL}$ and $\mathrm{HrpS}$ are not targets of CsrA, whereas three CsrA targets (relA, $r c s B$, and $f l h D)$ were identified and confirmed by REMSA, site-directed mutagenesis, and LacZ reporter gene assays. These findings might partially explain how CsrA positively controls $E$. amylovora virulence by targeting major regulators at the posttranscriptional level.

Keywords: bacterial pathogenesis, CsrA, genomics, posttranscriptional regulation, small noncoding RNAs, RNA-binding protein, T3SS, twocomponent system

Current address for V. Ancona: Citrus Center, Texas A\&M UniversityKingsville, Weslaco, TX 78599, U.S.A.

Current address for T. Chatnaparat: Department of Plant Pathology, Faculty of Agriculture, Kasetsart University, Bangkok 10900, Thailand

${ }^{\dagger}$ Corresponding author. Y. Zhao; zhao888@illinois.edu

Funding: This project was supported by the Agriculture and Food Research Initiative (USDA-AFRI) Competitive Grants Program grant number 2016-6701324812 from the United States Department of Agriculture-National Institute of Food and Agriculture and USDA-Hatch Project ILLU-802-913 (to Y. Zhao).

*The $\boldsymbol{e}$-Xtra $\log$ o stands for "electronic extra" and indicates that three supplementary figures and five supplementary tables are published online.

The author(s) declare no conflict of interest.

(c) 2019 The American Phytopathological Society
Erwinia amylovora, a gram-negative bacterium belonging to the Enterobacteriaceae family, is the causal agent of the economically important fire blight disease in apple and pear trees. The bacterium utilizes two pathogenicity factors to cause disease: a hypersensitive response and pathogenicity (hrp)type III secretion system (T3SS) and the exopolysaccharide (EPS) amylovoran (Khan et al. 2012; Zhao 2014; Zhao et al. 2009). The hrp-T3SS translocates effector proteins directly into host cells, thus interfering with host immunity (Büttner 2012; Zhao 2014). The expression of $h r p$-T3SS genes is activated by the master regulator $\mathrm{HrpL}$, an alternative $\sigma$ factor (McNally et al. 2012; Wei and Beer 1995), where expression of the $h r p L$ gene is regulated by another alternative $\sigma$ factor (RpoN) and other transcription factors, including $\mathrm{YhbH}$, HrpS, integration host factor (IHF), (p)ppGpp, and DksA, all of which are indispensably required for transcription initiation and control of HrpL activity (Ancona et al. 2014; 2015b; Lee and Zhao 2016; Lee et al. 2018). On the other hand, the EPS amylovoran plays a major role in biofilm formation and cell survival during late stages of the infection process (Koczan et al. 2009; Nimtz et al. 1996). Genes encoding EPS amylovoran biosynthesis components are clustered in the ams operon and primarily activated by the Rcs phosphorelay system (Bernhard et al. 1993; Lee and Zhao 2018; Wang et al. 2009, 2012).

The Csr system, which was first reported in Escherichia coli as a regulator of glycogen biosynthesis, is one of the major posttranscriptional regulators in bacteria (Vakulskas et al. 2015). It consists of the carbon storage regulator CsrA (or its homologs RsmA and RsmE, repressor of secondary metabolites) and its regulatory noncoding small RNAs (ncsRNAs) (Babitzke and Romeo 2007). CsrA predominantly binds to a GGA motif in a hairpin structure at the $5^{\prime}$ untranslated region of mRNA, leading to RNA stabilization or destabilization, and translation activation or repression (Andrade et al. 2014; Vakulskas et al. 2015; Yakhnin et al. 2013). Recently, changes in RNA secondary structures caused by CsrA binding were also found to affect $\rho$-dependent termination and riboswitch confirmation, suggesting diverse regulatory action of CsrA at the posttranscriptional level (FigueroaBossi et al. 2014; Patterson-Fortin et al. 2013). On the other hand, ncsRNAs such as csrB in Erwinia amylovora, $r s m B$ in Pectobacterium carotovorum and Dickeya dadantii, and $\operatorname{csr} B$ and $c s r C$ in Escherichia coli and Salmonella enterica contain a number of GGA motifs, which sequester CsrA and inhibit its activity (Babitzke and Romeo 2007). In $\gamma$-proteobacteria, expression of ncsRNAs is specifically dependent on the BarA/UvrY twocomponent system or its homologs such as GrrS/GrrA of Erwinia amylovora (Li et al. 2014; Suzuki et al. 2002; Zere et al. 2015). Other regulators such as RNA helicases, IHF, CsrD, (p)ppGpp, and DksA have also been reported to play a role in regulating 
ncsRNAs (Edwards et al. 2011; Lee and Zhao 2016; Suzuki et al. 2006; Vakulskas et al. 2014).

Accumulating evidence showed that the Csr system greatly affects virulence gene regulation in diverse pathogenic bacteria. In the genus Salmonella, CsrA suppresses the expression of HilD, which acts as a central regulator in the activation of Salmonella pathogenicity island-1 (SPI-1) and SPI-2 (Martínez et al. 2011). In Legionella pneumophila, CsrA negatively regulates the expression of flagellar biosynthesis activator FleQ and quorum-sensing component LqsR. It also directly interacts with transcripts of Dot/Icm type IV secretion system effectors (Sahr et al. 2017). RsmA of Xanthomonas citri subsp. citri protects the $h r p G$ transcript, encoding the master regulator of T3SS, from RNase E cleavage and allows T3SS gene expression (Andrade et al. 2014). In E. amylovora, the Csr system is a key virulence regulator activating T3SS, amylovoran production, and motility, while the $g r r S / g r r A$, ihf, and $\operatorname{csr} B$ mutants exhibited increased expression of those factors (Ancona et al. 2016; Lee and Zhao 2018; Lee et al. 2018; Li et al. 2014). However, target transcripts of CsrA remain unknown.

In E. amylovora, the Csr system has been shown to be closely associated with other important virulence regulators. It was reported that expression of $c s r B$ is under the control of IHF and the Rcs system (Lee and Zhao 2016; Lee et al. 2018). The nucleoid-associated protein IHF is involved in various DNAdependent processes, including cell division, transcription, and site-specific recombination, via DNA remodeling (Ali Azam et al. 1999; Dillon and Dorman 2010). Transcriptional initiation of $h r p L$ also requires IHF to enable interaction between transcription activators such as RpoN and HrpS (Lee and Zhao 2016; Lee et al. 2016). The Rcs system acts as a central two-component system that regulates major virulence factors of $E$. amylovora, including the T3SS, amylovoran production, and motility (Ancona et al. 2015a; Lee et al. 2018; Wang et al. 2012). Furthermore, Lon, an ATP-dependent protease, is also reported to be linked to the Csr system. Absence of Lon resulted in the accumulation of the RcsA and RcsB proteins, which suppress $c s r B$ expression, while absence of CsrA resulted in differential expression of lon at both transcriptional and posttranscriptional levels (Lee et al. 2018). These findings suggest that E. amylovora
CsrA could respond to both internal and external stimuli and act as a key component in the regulatory networks that coordinate the expression of different virulence factors.

In this study, we determined the global effect of CsrA and $\operatorname{csr} B$ at the transcriptional level, and examined the molecular mechanisms of CsrA-dependent virulence regulation in E. amylovora. Transcriptomic analysis under the T3SSinducing condition revealed that mutation of $c s r A$ resulted in differential expression of hundreds of genes, including those involved in virulence and important physiological processes. A direct physical interaction between CsrA protein and $\operatorname{csr} B$ ncsRNA was confirmed, and several CsrA target transcripts involved in the regulation of T3SS, amylovoran production, and motility were determined, providing partial explanation of CsrA-dependent virulence regulation in E. amylovora.

\section{RESULTS}

Csr $\mathrm{A}$ acts as a global regulator under the T3SS-inducing condition.

In a previous study, we showed that CsrA is required for virulence in E. amylovora by acting as an essential activator of T3SS, amylovoran production, and motility (Ancona et al. 2016). In order to further understand its global effect, RNA-seq comparing the wild type (WT) and the $\operatorname{csr} A$ and $\operatorname{csr} B$ mutants grown under the T3SS-inducing condition was conducted. In total, $13,370,077$ to $18,030,556$ reads from each biological sample were generated, and the percentage of reads mapped to E. amylovora genome ranged from 96 to $98 \%$. The $\log _{2}$ fold change (FC)/mean of normalized counts plots were generated to visualize expression pattern of individual genes (Supplementary Fig. S1). Principal component analysis (PCA) clearly showed that the first two components explained approximately $82 \%$ of the variability in the dataset, and the PCA plot showed a clear separation of the WT from the $\operatorname{csrA}$ and $c s r B$ mutants, which were clustered together (Supplementary Fig. S2). Differentially expressed genes (DEGs), which exhibited a $\left|\log _{2} \mathrm{FC}\right|$ value $\geq 1$ and a corrected $P$ value $<0.05$ between the WT and the mutants, were also functionally categorized based on the clusters of orthologous groups (COGs) in Figure 1.
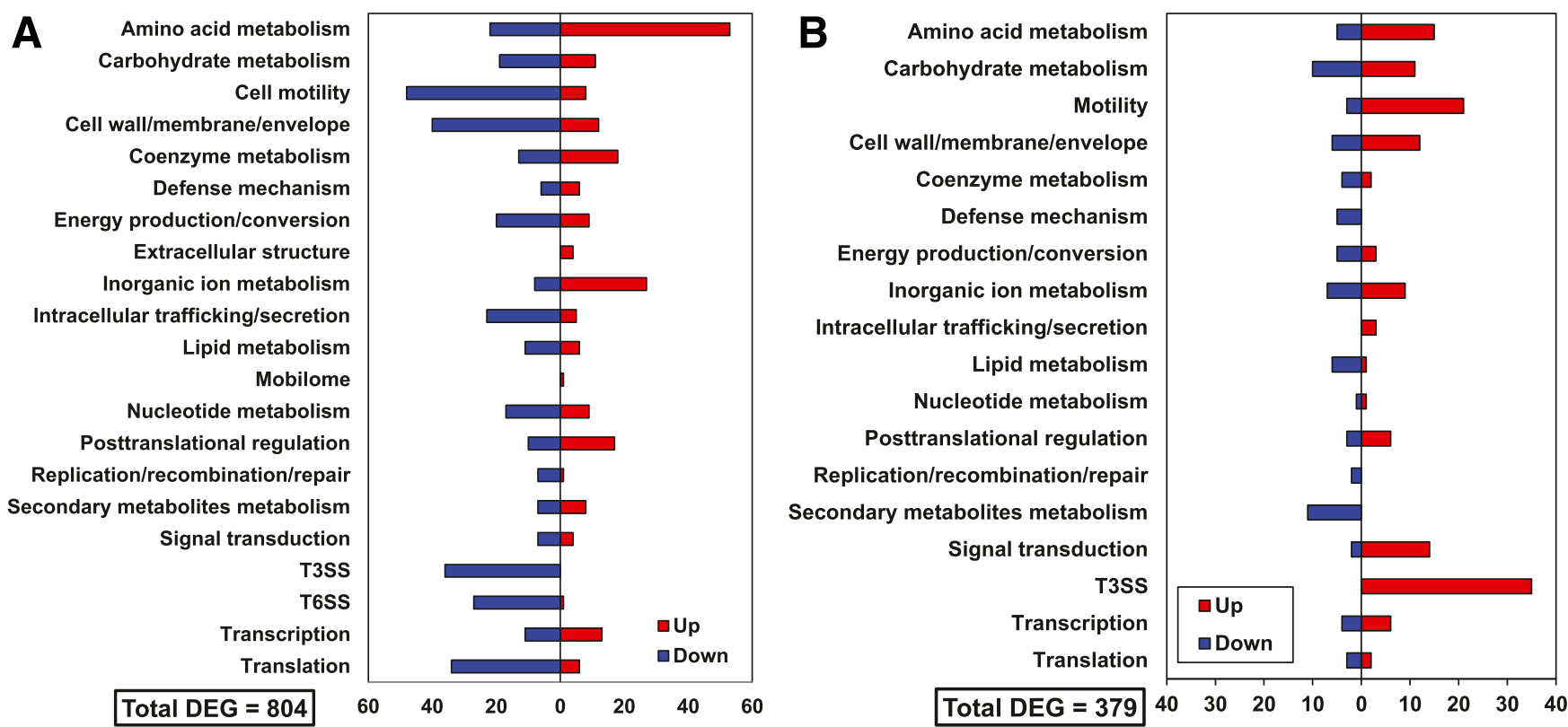

Fig. 1. Differential gene expression of the A, $\operatorname{csr} A$ and $\mathbf{B}, \operatorname{csr} B$ mutants compared with the wild type under the type III secretion system (T3SS)-inducing conditions. Functional classification of differentially expressed genes (DEGs) based on the clusters of orthologous groups (COGs). DEGs were defined as genes with a $\mid \log _{2}$ fold change $\mid$ value $\geq 1$ and a corrected $P$ value $<0.05$ from three independent biological replicates. T6SS $=$ type VI secretion system. 
In total, 804 genes, more than $20 \%$ of genes in the E. amylovora genome, were directly or indirectly affected in the csrA mutant, including 317 upregulated genes and 487 downregulated genes (Fig. 1A; Supplementary Table S1). In addition to the functional and regulatory components of T3SS, other virulence genes, including those encoding motility and the type VI secretion system, were rarely expressed in the $\operatorname{csr} A$ mutant (Table 1), further indicating that CsrA is critical for virulence activation in E. amylovora. Moreover, many genes responsible for important cellular processes, including nucleotide biosynthesis, electron transport chain, and ribosomal biosynthesis, were also significantly downregulated, whereas heat-shock response and sulfur metabolism genes were upregulated in the csrA mutant. These dramatic physiological perturbations might explain the nonpathogenic, nomotility. and slow-growth phenotypes in the csrA mutant (Ancona et al. 2016). On the other hand, 379 DEGs, including 171 upregulated and 208 downregulated genes, were observed in the $\operatorname{csr} B$ mutant (Supplementary Table S2). Compared with the $\operatorname{csr} A$ mutant, DEGs of the $\operatorname{csr} B$ mutant exhibited relatively

Table 1. Group I differentially expressed genes in hypersensitive response and pathogenicity (hrp)-inducing medium ${ }^{\mathrm{a}}$

\begin{tabular}{|c|c|c|c|}
\hline Gene ID & Gene description $^{b}$ & $\log _{2} \mathrm{FC} \Delta c s r A / \mathrm{WT}$ & $\log _{2} \mathrm{FC} \Delta \operatorname{csr} B / \mathrm{WT}$ \\
\hline EAMY_0491 & lidJ, disulphide bond formation protein & -1.31 & 2.84 \\
\hline EAMY_0492 & Phytochelatin synthase & -1.09 & 3.41 \\
\hline EAMY_0519 & hrpK, T3SS, pathogenicity locus protein & -2.39 & 2.07 \\
\hline EAMY_0520 & $h s v A$, T3SS, Hrp-associated systemic virulence protein & -2.52 & 3.47 \\
\hline EAMY_0521 & $h s v B$, T3SS, Hrp-associated systemic virulence protein & -1.47 & 3.40 \\
\hline EAMY_0522 & $h s v C$, T3SS, Hrp-associated systemic virulence protein & -1.10 & 2.52 \\
\hline EAMY_0524 & biphenyl 2,3-dioxygenase & -4.40 & 1.80 \\
\hline EAMY_0525 & $h r c U$, T3SS, type III secretion protein & -3.17 & 1.71 \\
\hline EAMY_0526 & $h r c T, \mathrm{~T} 3 \mathrm{SS}$, type III secretion apparatus protein & -2.66 & 1.90 \\
\hline EAMY_0527 & $h r c S$, T3SS, type III secretion protein & -4.29 & 1.89 \\
\hline EAMY_0528 & $h r c R$, T3SS, type III secretion apparatus protein & -3.76 & 1.93 \\
\hline EAMY_0529 & $h r c Q, \mathrm{~T} 3 \mathrm{SS}$, type III secretion system apparatus protein & -3.12 & 1.80 \\
\hline EAMY_0530 & $h r p P$, T3SS, type III secretion protein & -4.35 & 1.80 \\
\hline EAMY_0531 & $h r p O, \mathrm{~T} 3 \mathrm{SS}$, type III secretion protein & -5.30 & 1.81 \\
\hline EAMY_0532 & $h r c N$, T3SS, type III secretion system ATPase & -4.90 & 1.78 \\
\hline EAMY_0533 & $h r p Q, \mathrm{~T} 3 \mathrm{SS}$, type III secretion system protein & -5.79 & 1.83 \\
\hline EAMY_0534 & $h r c \widetilde{V}$, T3SS, type III secretion inner-membrane protein & -5.45 & 1.78 \\
\hline EAMY_0535 & $h r p J$, T3SS, type III secretion system protein & -5.59 & 1.73 \\
\hline EAMY_0536 & $h r p L$, T3SS, RNA polymerase $\sigma$ factor & -5.58 & 1.68 \\
\hline EAMY_0542 & hrpA, T3SS, Hrp pili protein & -6.87 & 1.72 \\
\hline EAMY_0543 & $h r p B$, T3SS, type III secretion system protein & -6.20 & 1.67 \\
\hline EAMY_0544 & $h r c J$, T3SS, type III secretion inner-membrane protein & -5.78 & 1.66 \\
\hline EAMY_0545 & $h r p D$, T3SS, type III secretion protein & -5.43 & 1.73 \\
\hline EAMY_0546 & hrpE, T3SS, type III secretion apparatus protein & -3.94 & 1.81 \\
\hline EAMY_0547 & $h r p F$, T3SS, type III secretion protein & -5.67 & 1.73 \\
\hline EAMY_0548 & $h r p G$, T3SS, type III secretion protein & -5.57 & 1.73 \\
\hline EAMY_0549 & $h r c C$, T3SS, type III secretion system outer membrane pore & -5.07 & 1.78 \\
\hline EAMY_0550 & $h r p T$, T3SS, type III secretion lipoprotein & -4.71 & 1.79 \\
\hline EAMY_0551 & $h r p V, \mathrm{~T} 3 \mathrm{SS}$, type III secretion protein & -4.75 & 1.75 \\
\hline EAMY_0552 & $h r p N, \mathrm{~T} 3 \mathrm{SS}$, harpin protein & -6.50 & 1.98 \\
\hline EAMY_0553 & orfA, T3SS, Tir chaperone family protein & -4.81 & 1.79 \\
\hline EAMY_0554 & $\operatorname{orf} B, \mathrm{~T} 3 \mathrm{SS}$, avirulence protein & -3.78 & 1.71 \\
\hline EAMY_0555 & orfC, T3SS, HrpW-specific chaperone & -5.28 & 1.80 \\
\hline EAMY_0556 & $h r p W, \mathrm{~T} 3 \mathrm{SS}$, harpin protein & -5.82 & 1.90 \\
\hline EAMY_0557 & $d s p E$, T3SS, Hrp secreted pathogenicity-like protein & -5.20 & 1.58 \\
\hline EAMY_0558 & $d s p F$, T3SS, Hrp secreted pathogenicity-like protein & -5.20 & 1.57 \\
\hline EAMY_0653 & eop2, T3SS, type III effector & -3.62 & 1.85 \\
\hline EAMY_1450 & flgN, motility, flagella synthesis protein & -1.77 & 1.64 \\
\hline EAMY_1451 & flgM, motility, negative regulator of flagellin synthesis & -2.16 & 1.70 \\
\hline EAMY_1462 & $f l g K$, motility, flagellar hook-associated protein & -1.83 & 1.65 \\
\hline EAMY_1463 & flgL, motility, flagellar hook-associated protein & -1.92 & 1.75 \\
\hline EAMY_1498 & rcs $A$, colanic acid capsular biosynthesis activation protein & -1.42 & 2.73 \\
\hline EAMY_2094 & cheW, motility, chemotaxis signal transduction protein & -2.07 & 1.33 \\
\hline EAMY_2095 & cheA, motility, chemotactic sensory histidine kinase & -2.21 & 1.44 \\
\hline EAMY_2096 & $m o t B$, motility, flagellar motor protein & -2.25 & 1.57 \\
\hline EAMY_2097 & $m o t A$, motility, flagellar motor protein & -2.96 & 1.46 \\
\hline EAMY_2134 & yed $O, 1$-aminocyclopropane-1-carboxylate deaminase & -1.83 & 1.48 \\
\hline EAMY_2135 & $D$-cysteine desulfhydrase & -1.45 & 1.41 \\
\hline EAMY_2139 & fliA, motility, RNA polymerase $\sigma$ factor & -5.35 & 1.09 \\
\hline EAMY_2141 & $f l i C$, motility, filament structural protein & -3.22 & 3.42 \\
\hline EAMY_2142 & fliD, motility, flagellar capping protein & -2.71 & 1.62 \\
\hline EAMY_2143 & fliS, motility, flagellin-specific chaperone & -2.72 & 1.26 \\
\hline EAMY_2144 & fliT, motility, flagellar export chaperone & -1.85 & 1.23 \\
\hline EAMY_2218 & yeeF, putrescine transporter & -1.16 & 1.03 \\
\hline EAMY_2275 & aro $Q$, chorismate mutase & -1.42 & 1.43 \\
\hline EAMY_2945 & Acyltransferase & -1.16 & 1.79 \\
\hline EAMY_3175 & avrRpt2, T3SS, cysteine protease avirulence protein & -1.61 & 1.54 \\
\hline
\end{tabular}

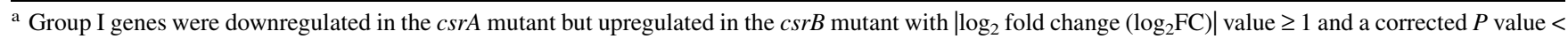
0.05 between the wild type (WT) and the mutants.

b T3SS = type III secretion system. 
less fluctuation in transcription levels across the genome, including metabolic and stress responsive genes (Fig. 1B). The expression of genes responsible for all of the major virulence factors, including T3SS, EPS amylovoran, and motility, was significantly increased in the $\operatorname{csr} B$ mutant. This is consistent with the results from phenotypic data of our previous studies (Ancona et al. 2016; Li et al. 2014).

Though many DEGs in both the $\operatorname{csr} A$ and $\operatorname{csr} B$ mutants were annotated as hypothetical proteins, Venn diagrams (Fig. 2A) identified four groups of genes whose expression might be closely associated with the Csr system. Group I included 68 genes that were downregulated in the $\operatorname{csr} A$ mutant but upregulated in the $\operatorname{csr} B$ mutant, including mostly T3SS and flagellar genes (Table 1). Expression of the $r c s A$ gene also exhibited the same trend, whereas expression of the $r \operatorname{cs} B, r c s C$, and $r \operatorname{cs} D$ genes in the Rcs system was not significantly changed in either mutant (Table 1), suggesting that CsrA might positively regulate the Rcs system at the posttranscriptional level. Group II contained 33 genes that were upregulated in the $\operatorname{csr} A$ mutant but downregulated in the $\operatorname{csr} B$ mutant, including $r c s V$ (LuxR-family transcriptional regulator), narPQ (two-component system), ompT (outer membrane protease), and CRISPR (clustered regularly interspaced short palindromic repeat)-associated (Cas) protein genes (Table 2). Interestingly, the $r c s V$ gene was approximately 60-fold upregulated and the most differentially expressed in the csrA mutant, whereas it was 3-fold downregulated in the $\operatorname{csr} B$ mutant.

Groups III and IV included 20 and 97 genes, respectively, that were significantly upregulated or downregulated in both mutants. Posttranslational regulators such as ATP-dependent protease $h s l U V$ genes; molecular chaperone groEL and $h t p G$ genes; and sulfur transport systems, including tauABCD (EAMY_3404 to EAMY_3407) and ssuEADC (EAMY_1370 to EAMY_1373) gene clusters, were all upregulated (Supplementary Table S3), whereas genes encoding glycosyltransferase, lipoproteins, and membrane-associated proteins were all downregulated (Supplementary Table S4). To validate RNA-seq data, nine representative DEGs of the $\operatorname{csr} A$ or $\operatorname{csr} B$ mutant were randomly selected, and their expression was determined in the $h r p$-inducing medium (HMM) using real-time quantitative reverse-transcription (qRT)-PCR (Fig. 2B). Although a different magnitude of the fold change was observed in the T3SS genes such as $h r p L$ and $h s v A$, all genes tested showed similar trends between qRT-PCR and RNA-seq results, suggesting that our results are reliable and reproducible.

\section{CsrA does not directly interact}

\section{with hrpL and hrpS transcripts.}

It is assumed that $\operatorname{csr} B$ ncsRNA acts antagonistically to regulate CsrA in E. amylovora; however, their direct interaction was not experimentally confirmed (Ancona et al. 2016). RNA electrophoretic mobility shift assay (REMSA) analysis showed that $\operatorname{csr} B$ sRNA led to a band shift with as low as $10 \mathrm{nM}$ CsrA protein (Fig. 3A), indicating that binding affinity between $\operatorname{csr} B$ ncsRNA and CsrA is high. On the other hand, both $h r p L$ and $h r p S$ are barely expressed in the $c s r A$ mutant but are significantly upregulated in the $\operatorname{csr} B$ mutant, suggesting that $h r p L$ or hrpS transcripts might be the direct targets of CsrA (Ancona et al. 2016; Lee and Zhao 2018). However, REMSA showed no interaction between CsrA protein and both $h r p L$ and $h r p S$ RNA probes (Fig. 3A), suggesting that CsrA does not directly target $h r p L$ and $h r p S$ transcripts and might target other regulatory genes involved in the regulation of T3SS gene expression.

\section{CsrA is required for efficient translation of relA.}

In E. amylovora, the nucleotide second messenger (p)ppGpp is a key activator of T3SS gene expression by activating the
RpoN-HrpL alternative $\sigma$ factor cascade and $h r p S$ expression through HrpX/HrpY (Ancona et al. 2016; Lee and Zhao 2018). Because our transcriptomic analysis showed that major T3SS regulators under (p)ppGpp control are differentially expressed in the $\operatorname{csr} A$ mutant but the transcript levels of (p)ppGpp biosynthesis genes relA and spoT are not significantly changed (Ancona et al. 2015b; Lee and Zhao 2018), we hypothesized that CsrA might be involved in their regulation at the posttranscriptional level. REMSA showed a direct interaction between CsrA and relA and spoT RNA probes (Fig. 3), but only expression of the relA gene from the translational fusion construct was slightly reduced in the $\operatorname{csrB}$ mutant (Fig. 4A). Secondary structure analysis showed two hairpin loop structures containing the putative CsrA-binding sites in the relA leader sequence (Fig. 4B). To further examine the role of CsrA on the relA translation, the putative CsrA-binding site near the putative Shine-Dalgarno sequence was mutated from GGA to GGG to eliminate CsrA-binding effect without affecting RNA secondary structure (Fig. 4B). Translation of the relA gene in both the WT and the $\operatorname{csr} B$ mutant was decreased to approximately $80 \%$ after mutation in the GGA motif (Fig. 4C), indicating that CsrA binding contributes to efficient relA expression. However, it is still unclear whether spoT is also a direct target of CsrA based on our current data.
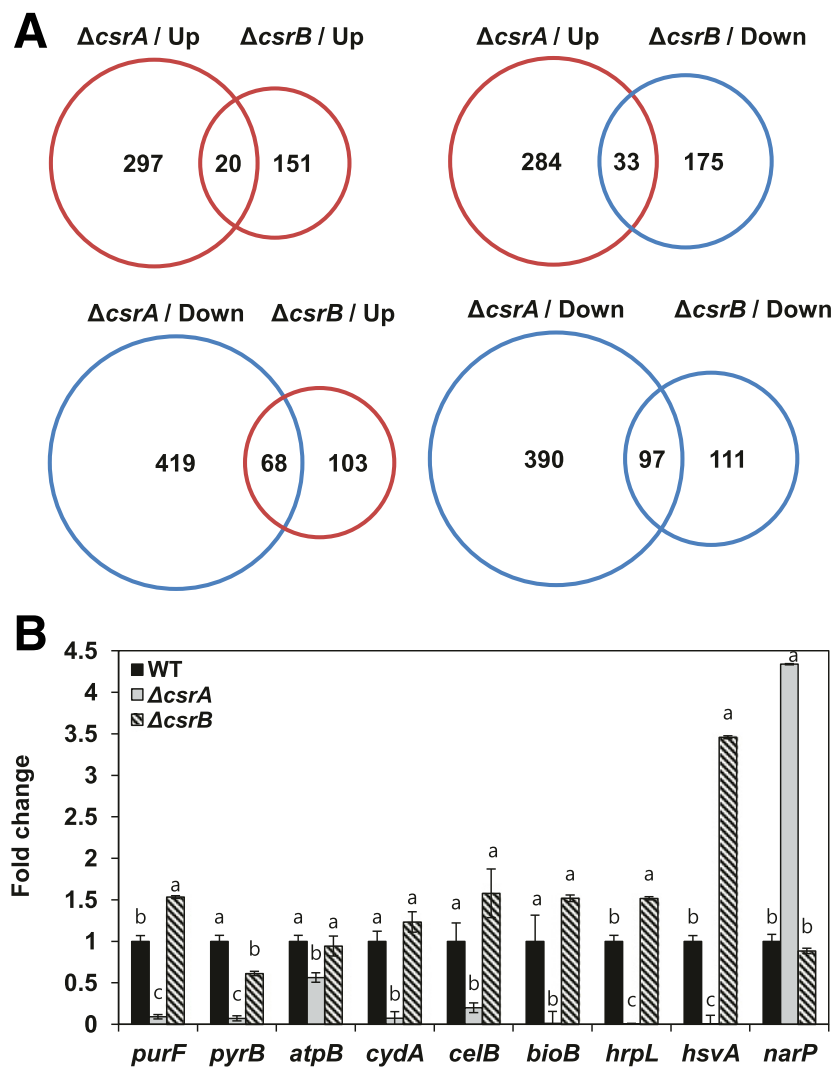

Fig. 2. A, Venn diagrams show overlapping and unique differentially expressed genes (DEGs) between the $c s r A$ and $c s r B$ mutants. DEGs were defined as genes with a $\mid \log _{2}$ fold change| value $\geq 1$ and a corrected $P$ value $<0.05$ from three independent biological replicates. B, Validation of RNAseq data. Relative gene expression of the selected genes in the $c s r A$ and $c s r B$ mutants compared with the wild type (WT) grown in hypersensitive response and pathogenicity ( $h r p$ )-inducing medium at $18^{\circ} \mathrm{C}$ for $6 \mathrm{~h}$. The $r p o D$ gene was used as an endogenous control. Values of the relative fold change were the means of three replicates, and values with the same letter in each gene do not differ significantly $(P<0.05)$. Error bars indicate standard deviation. 
CsrA positively regulates $r c s B$ expression at the posttranscriptional level.

Previous genetic studies and transcriptomic analysis showed increased expression of many Rcs-dependent genes in the $c s r B$ mutant, including $r c s A, h r p S$, and ams operon genes; thus, we hypothesized that the activity of the Rcs system might be positively regulated by CsrA (Lee and Zhao 2018; Lee et al. 2018). REMSA analyses showed that CsrA specifically binds to the leader sequence of $r c s B$ (Fig. 5A and B; Supplementary Fig. S3). Under the T3SS-inducing condition, transcript level of the $r c s B$ gene was not changed in the $\operatorname{csr} B$ mutant (Lee et al. 2018); however, expression of $r c s B$ from the translational fusion construct increased approximately 1.5 -fold. No increase was observed for the $r c s D$ gene, which is in the same operon as $r c s B$ (Fig. 5C). These results suggest that binding of CsrA to the $r \operatorname{cs} B$ transcript positively regulates $r c s B$ expression at the posttranscriptional level.

\section{CsrA positively regulates motility through $f l h D$ at the posttranscriptional level.}

One of the well-studied CsrA target transcript in Escherichia coli is $f l h D$, encoding the master regulator of flagellar gene expression. It has been shown that CsrA binds to the leader sequence of $f l h D$ and increases its translation by protecting the transcript from RNase E-mediated cleavage (Wei et al. 2001; Yakhnin et al. 2013). Although the leader sequences of $f l h D$ in E. coli and Erwinia amylovora are not homologous, genetic analyses suggested that CsrA positively regulates motility in E. amylovora, possibly through flhD (Ancona et al. 2016; Lee and Zhao 2016; Li et al. 2014). To determine its underlying mechanism, expression of different classes of flagellar gene using transcriptional fusion constructs in the $\operatorname{csr} B$ mutant was measured in tryptone broth (TB) (Fig. 6A). Compared with the WT, expression of class II and class III flagellar genes (fliL, fliA, flgM, and fliD) increased approximately threefold, whereas expression of a class I flagellar gene $(f l h D)$ was not considerably changed, suggesting that posttranscriptional regulation might occur in the $f l h D$ gene. REMSA showed that

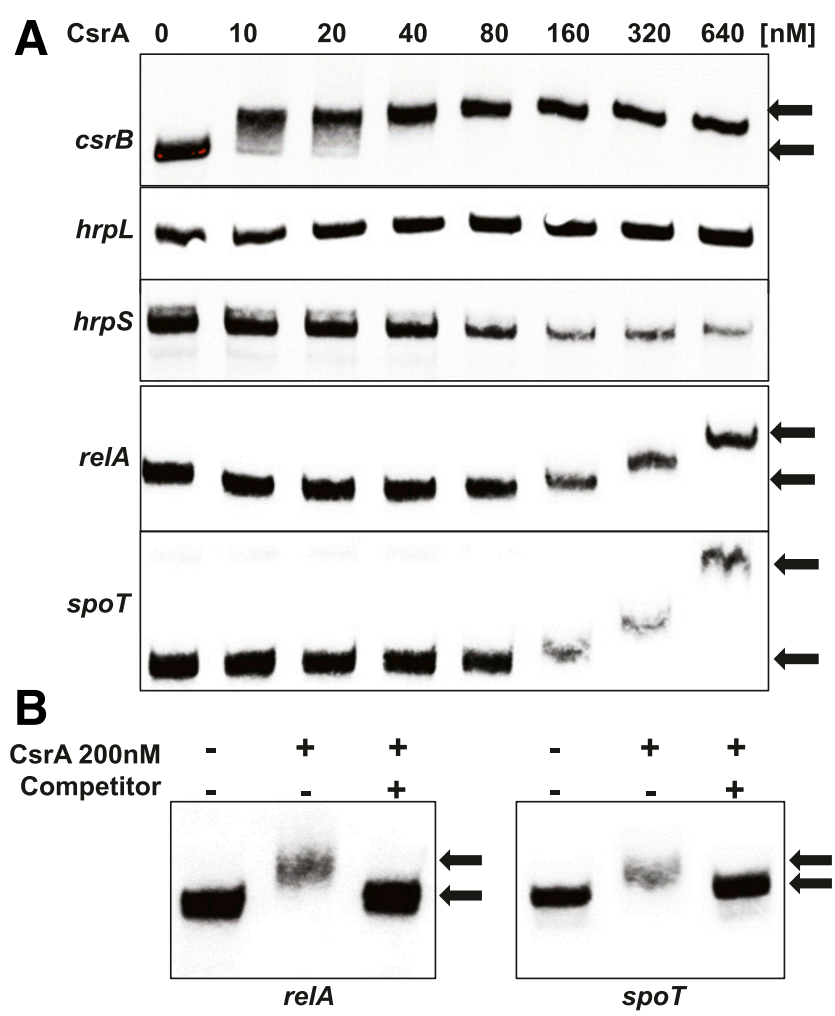

Fig. 3. A, Gel shift assays (RNA electrophoretic mobility shift assay) of CsrA interacts with the leader sequences of $\operatorname{csr} B, h r p L, h r p S$, relA, and spoT. Black arrows at the bottom and top indicate free probe and the protein-RNA complex, respectively. The concentration of protein (in nanomoles) is indicated above each lane. Experiments were repeated three times with similar results. B, Competition assays of interaction between CsrA and relA and spoT RNA probes by adding unlabeled $c s r B$ RNA. Black arrows at the bottom and top indicate free probe and the protein-RNA complex, respectively. The concentration of protein (in nanomoles) is indicated above each lane. Experiments were repeated three times with similar results.

Table 2. Group II differentially expressed genes in hypersensitive response and pathogenicity ( $h r p$ )-inducing medium ${ }^{\mathrm{a}}$

\begin{tabular}{|c|c|c|c|}
\hline Gene ID & Gene description ${ }^{b}$ & $\log _{2} \mathrm{FC} \Delta c s r A / \mathrm{WT}$ & $\log _{2} \mathrm{FC} \Delta c s r B / \mathrm{WT}$ \\
\hline EAMY_0054 & LuxR-family transcriptional regulator & 2.22 & -1.47722 \\
\hline EAMY_0249 & отрT, outer membrane protease & 1.13 & -1.01609 \\
\hline EAMY_0441 & Creatininase & 2.41 & -2.6658 \\
\hline EAMY_0442 & Dihydroorotate dehydrogenase & 2.51 & -2.74218 \\
\hline EAMY_0444 & mсуE, glutamate-1-semialdehyde aminotransferase & 2.84 & -2.9406 \\
\hline EAMY_0445 & mсуE, $\beta$-ketoacyl synthase & 2.18 & -2.36154 \\
\hline EAMY_0446 & irp, Polyketide synthase & 2.38 & -2.78833 \\
\hline EAMY_0447 & syp $C$, gramicidin $\mathrm{S}$ synthetase II & 2.50 & -2.96328 \\
\hline EAMY_0448 & pps $D$, polyketide synthase & 2.41 & -2.81697 \\
\hline EAMY_0449 & Polyketide synthase & 1.84 & -2.13904 \\
\hline EAMY_1738 & ynf $M$, major facilitator superfamily transporter & 1.80 & -1.03952 \\
\hline EAMY_2423 & $f a b B, 3$-oxoacyl-(acyl-carrier-protein) synthase & 2.87 & -1.15477 \\
\hline EAMY_2475 & Hypothetical protein & 1.44 & -1.81294 \\
\hline EAMY_2506 & nar $Q$, two-component system histidine kinase & 1.15 & -1.44746 \\
\hline EAMY_2552 & Major facilitator superfamily transporter & 3.62 & -1.22834 \\
\hline EAMY_2800 & $r c s V$, LuxR-family transcriptional regulator & 5.85 & -1.68411 \\
\hline EAMY_2813 & ygbF, CRISPR-associated protein Cas2 & 1.32 & -1.70694 \\
\hline EAMY_2814 & ygbT, CRISPR-associated protein Cas1 & 1.29 & -2.01252 \\
\hline EAMY_2815 & ygcH, Cse3-family CRISPR-associated protein & 1.12 & -2.10032 \\
\hline EAMY_2816 & ygcI, CRISPR-associated protein Cas5 & 1.21 & -2.21313 \\
\hline EAMY_2817 & ygcJ, Cse4-family CRISPR-associated protein & 1.39 & -2.2221 \\
\hline EAMY_2818 & ygcK, Cse2-family CRISPR-associated protein & 1.61 & -2.25029 \\
\hline EAMY_2819 & ygcL, Cse1-family CRISPR-associated protein & 1.90 & -2.20392 \\
\hline EAMY_2820 & y $c c B$, CRISPR-associated helicase Cas 3 & 1.68 & -1.68656 \\
\hline
\end{tabular}

${ }^{a}$ Group II genes were upregulated in the $c s r A$ mutant but downregulated in the $\operatorname{csr} B$ mutant with $\mid \log _{2}$ fold change $\left(\log _{2} \mathrm{FC}\right) \mid$ value $\geq 1$ and a corrected $P$ value $<$ 0.05 between the wild type (WT) and the mutants.

${ }^{\mathrm{b}}$ CRISPR $=$ clustered regularly interspaced short palindromic repeat. 

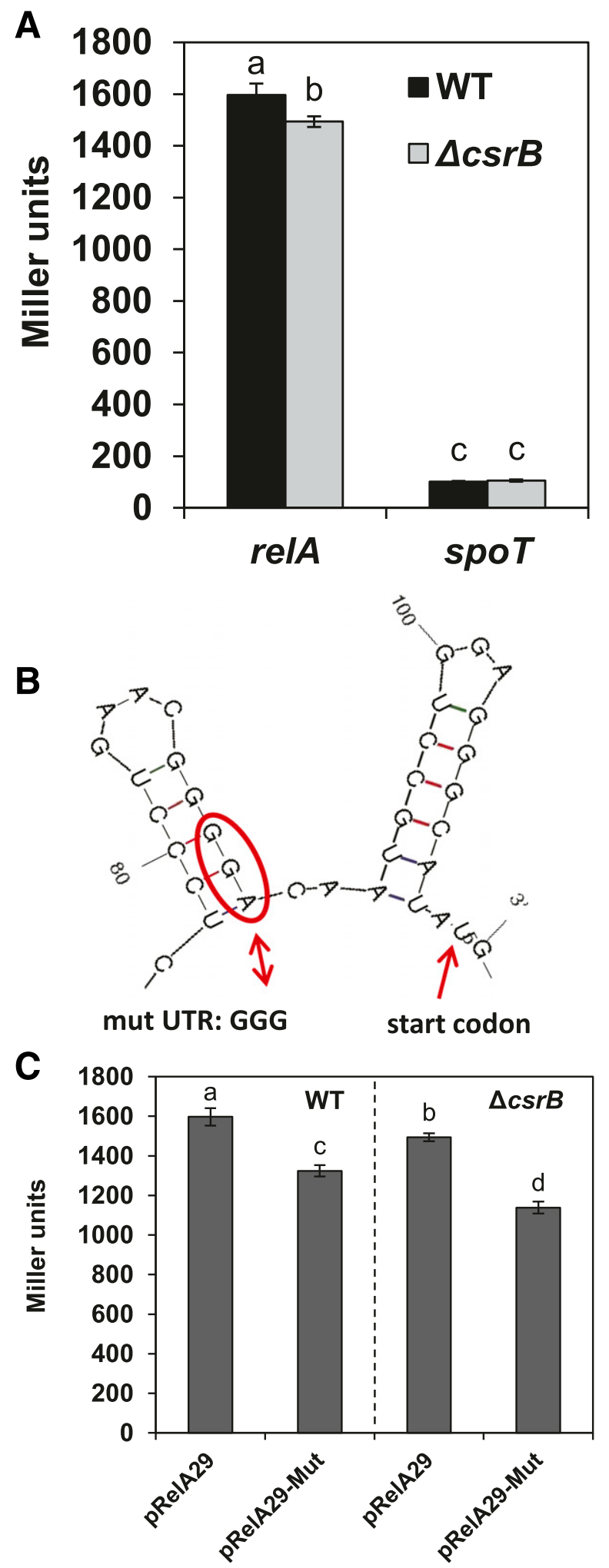

Fig. 4. CsrA is required for efficient translation of relA. A, LacZ activities of translational fusion constructs carrying upstream sequences of the relA and spoT genes in the wild type (WT) and the csrB mutant grown in hypersensitive response and pathogenicity ( $h r p$ )-inducing medium (HMM) at $18^{\circ} \mathrm{C}$ for $6 \mathrm{~h}$. Values of Miller units were the means of four replicates. B, Predicted secondary structure of the relA leader sequence. The putative CsrA-binding site and the start codon are indicated with the circle and arrow, respectively. C, LacZ activities of translational fusion constructs carrying different upstream sequences of the relA genes in the WT and the $c s r B$ mutant grown in $\mathrm{HMM}$ at $18^{\circ} \mathrm{C}$ for $6 \mathrm{~h}$. Values of Miller units were the means of four replicates, and the values with the same letter do not differ significantly $(P<0.05)$. Experiments were repeated three times with similar results.

CsrA directly and specifically binds to flhD RNA (Fig. 6B and C). A translational fusion reporter gene assay showed that expression of $f l h D$ increased approximately twofold in the $\operatorname{csr} B$ mutant as compared with that of the WT (Fig. 6D), indicating that CsrA positively regulates flhD expression at the posttranscriptional level in E. amylovora.

To further characterize CsrA-dependent $f l h D$ upregulation, each of four putative CsrA-binding sites (named GGA1 to GGA4) on the leader sequence of the $f l h D$ gene was deleted, and differential expression using translational fusion constructs was compared (Fig. 6E). In the WT, flhD expression was decreased after deletion of GGA1 and GGA4 whereas, in the $\operatorname{csr} B$ mutant, flhD expression was increased after deletion of GGA2 but decreased after deletion of GGA1, GGA3, and GGA4 (Fig. $6 \mathrm{~F})$. These results suggest that CsrA might bind to multiple sites of the $f l h D$ leader sequence, which leads to an increased translation rate of flhD in E. amylovora.

\section{DISCUSSION}

The RNA-binding protein CsrA is indispensable for virulence by positively regulating major virulence factors in E. amylovora, including T3SS and amylovoran (Ancona et al. 2016). In this study, we confirmed that CsrA is a global regulator not only of virulence gene expression but also of diverse

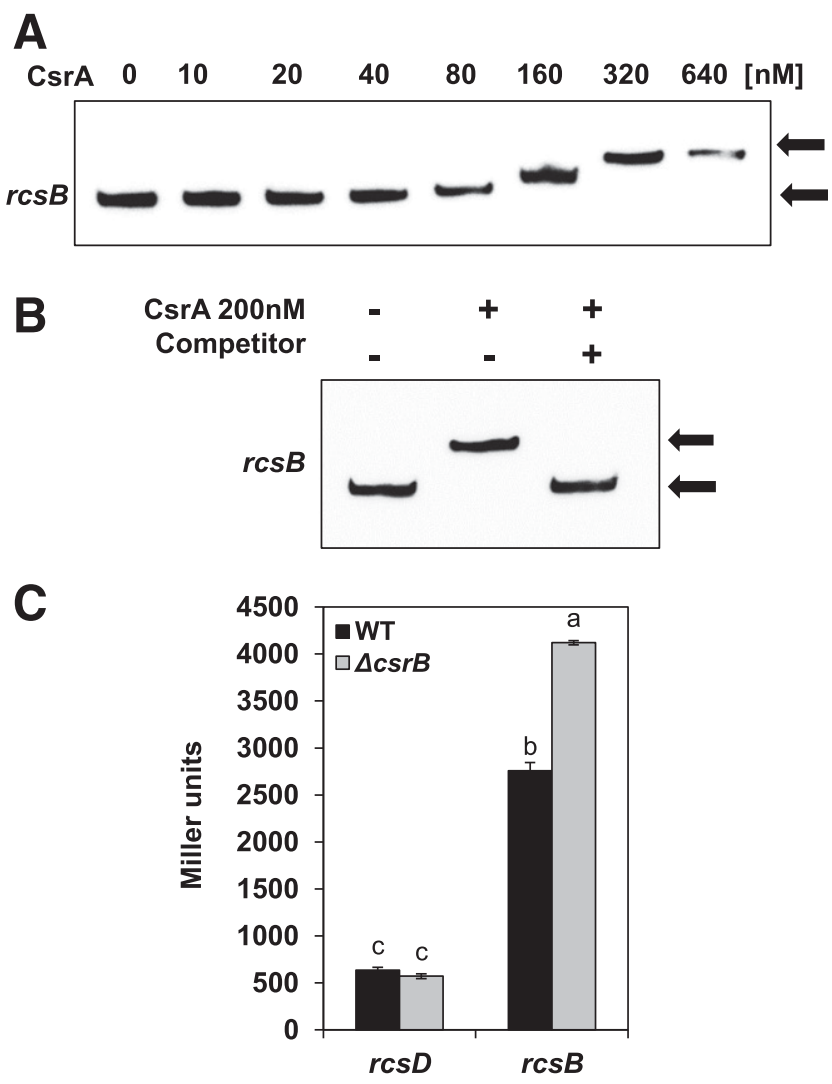

Fig. 5. CsrA positively regulates $r c s B$ expression at the posttranslational level. A, RNA electrophoretic mobility shift assay for CsrA binding to the leader sequence of $r c s B$. B, Competition assay of interaction between CsrA and $r c s B$ RNA by adding unlabeled $c s r B$ RNA. Black arrows at the bottom and top indicate free probe and the protein-RNA complex, respectively. The concentration of protein (in nanomoles) is indicated above each lane. $\mathbf{C}$, LacZ activities of translational fusion constructs carrying upstream sequences of the $r c s D$ and $r c s B$ genes in the wild type (WT) and the $\operatorname{csr} B$ mutant grown in hypersensitive response and pathogenicity ( $h r p$ )-inducing medium at $18^{\circ} \mathrm{C}$ for $6 \mathrm{~h}$. Values of Miller units were the means of four replicates, and the values with the same letter do not differ significantly $(P<$ 0.05). Experiments were repeated three times with similar results. 
cellular processes required for cell growth and viability. We also demonstrated that CsrA directly binds to $\operatorname{lih} D, r c s B$, and relA transcripts and positively regulates their expression at the posttranscriptional level, thus influencing major virulence factors and contributing to virulence in E. amylovora.

The global regulatory roles of CsrA have been studied in several species using deep sequencing. In transcriptomic analysis of $S$. typhimurium and Pseudomonas aeruginosa, a mutation in $\operatorname{csr} A$ led to 375 and 506 DEGs, respectively, compared with the WT, which are approximately $10 \%$ of total genes in each species (Burrowes et al. 2006; Lawhon et al. 2003). Recent studies using CsrA-RNA complex immunoprecipitation combined with deep sequencing approach (CLIP-seq) also revealed that, in S. typhimurium, L. pneumophila, and Campylobacter jujuni, CsrA directly interacts with approximately $10 \%$ of their total gene transcripts (Dugar et al. 2016; Holmqvist et al. 2016; Sahr et al. 2017). On the other hand, integration of different transcriptomic approaches in E. coli revealed that approximately 25 and $12.5 \%$ of total gene transcripts were differentially expressed in the $\operatorname{csr} A$ mutant and directly bound by CsrA in vivo, respectively (Potts et al. 2017). These reports collectively indicate that CsrA acts as a major posttranscriptional regulator in bacteria under different experimental conditions.
In this study, our results showed that approximately $20 \%$ of the genes in E. amylovora genome were differentially expressed in the absence of CsrA. Unlike other species examined, the DEGs included not only virulence genes but also many physiologically important genes. The $\operatorname{csr} A \mathrm{mu}-$ tant exhibited a significant downregulation of nucleotide biosynthesis, electron transport chain, and ribosomal biosynthesis, suggesting its incapability to maintain cell integrity. The $c s r A$ mutant also exhibited a significant upregulation of heat-shock genes. Given that transcription of heat-shock genes is triggered in response to various stress conditions, including temperature variations, toxic chemicals, desiccation, and viral infections, to protect intracellular proteins from denaturation and aggregation (Morimoto 1993), upregulation of these genes in the csrA mutant indicates unstable intracellular states. Consistently, it was reported in Escherichia coli that cells under heat-shock stress exhibited a downregulation of genes involved in ribosome assembly and energy metabolism (Murata et al. 2011), suggesting that a mutation in the csrA gene results in severe cellular stress. These results together showed that gene regulation and cell physiology in Erwinia amylovora is highly dependent on CsrA and, thus, its absence causes pleiotropic defects, including slow growth and nonpathogenic phenotypes (Ancona et al. 2016).

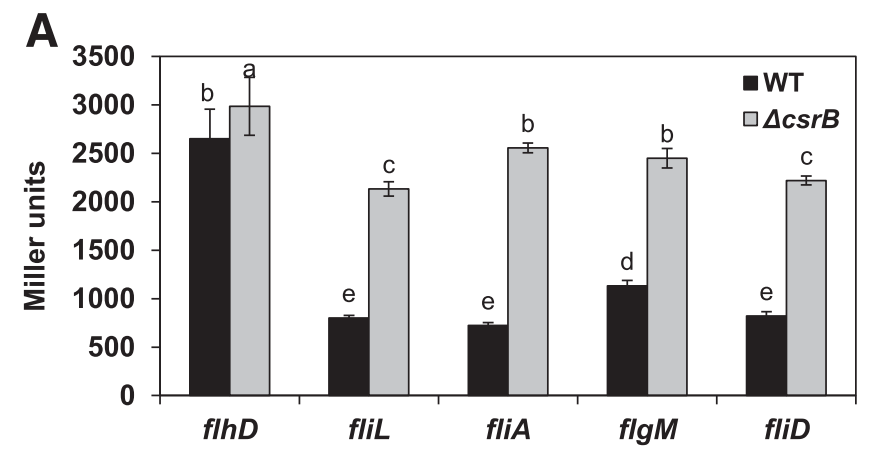

B

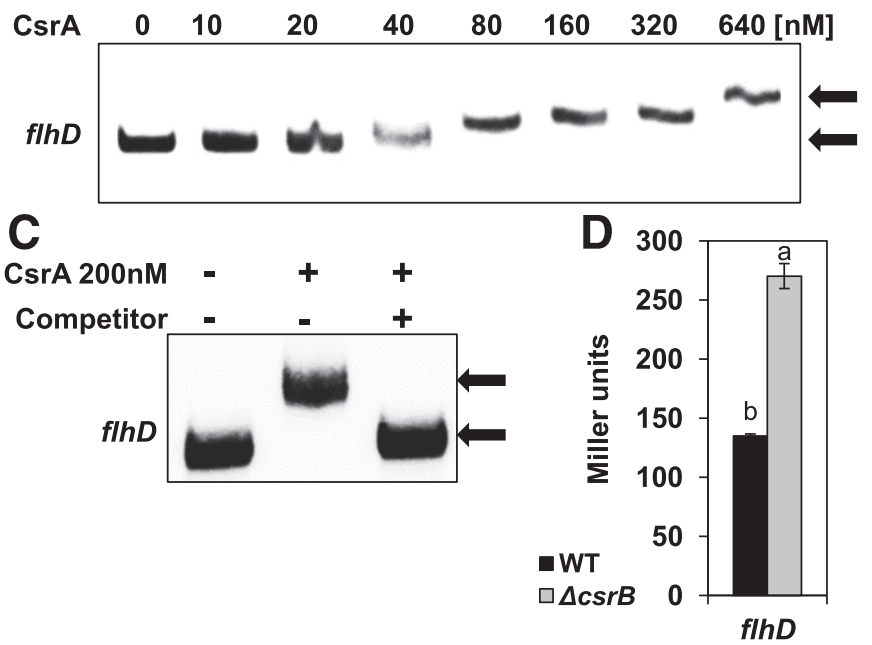

E

GCTTTAGGAATAGTCCTGGTAGAGTGCAACAAGAAGTC TSS (1)

ATAAAGGAAGAAGTCAGGGAAGAAGAGGCTCAGGAATA (2)

(3)

(4)

GCCGCTGGCAAAACGAGTCTATAATTATCTCTGGCTTA GTTTCTCGAACTAAGAAATAAGCCAGCTTTAGCTCATC TTTGGCTCCTGCCACTAAATATTTTGCCATCTTTAGAT CTACCAACCAGCAACCAGGTAGCGGTATCCACCGCGCA CGTTAAAAGCAGTGCTAGTCAGGATGGAAAAATG

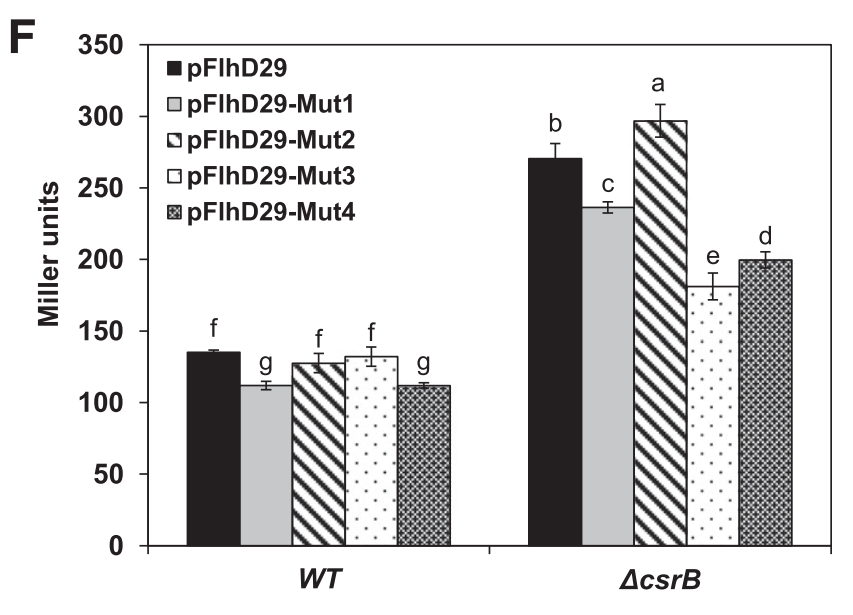

Fig. 6. CsrA positively regulates flhD expression at the posttranscriptional level. A, LacZ activities of transcriptional fusion constructs carrying upstream sequences of five different flagellar genes $(f l h D, f l i L, f l i A, f l g M$, and $f l i D)$ in the wild type (WT) and the $c s r B$ mutant grown in tryptone broth (TB) at $28^{\circ} \mathrm{C}$ for $6 \mathrm{~h}$. Values of Miller units were the means of four replicates. B, RNA electrophoretic mobility shift assay for CsrA binding to the leader sequence of $f l h D$. C, Competition assay of interaction between CsrA and flhD RNA by adding unlabeled $c s r B$ RNA. Black arrows at the bottom and top indicate free probe and the protein-RNA complex, respectively. The concentration of protein (nM) is indicated above each lane. $\mathbf{D}$, LacZ activities of translational fusion constructs carrying upstream sequences of the $f l h D$ gene in the WT and the $c s r B$ mutant grown in TB at $28^{\circ} \mathrm{C}$ for $6 \mathrm{~h}$. Values of Miller units were the means of four replicates, and the values with the same letter do not differ significantly $(P<0.05)$. Experiments were repeated three times with similar results. E, The leader sequence of the $f l h D$ gene. The transcription start site, four putative CsrA-binding sites, and ATG start codon are underlined. Each GGA motif was deleted using site-directed mutagenesis, and the four different mutated sequences were cloned into pZLac29. Plasmids were designated as pFlhD29-Mut1 to pFlhD29Mut4 and introduced into the WT and the $\operatorname{csr} B$ mutant. F, LacZ activities of translational fusion constructs carrying different upstream sequences of the flhD gene in the WT and the $\operatorname{csr} B$ mutant grown in TB at $28^{\circ} \mathrm{C}$ for $6 \mathrm{~h}$. Values of Miller units were the means of four replicates, and the values with the same letter do not differ significantly $(P<0.05)$. Experiments were repeated three times with similar results. 
Interestingly, five heat-shock genes ( $g r o E$, groL, hslU, hslV, and $h t p G)$ were upregulated in both the $\operatorname{csr} A$ and $\operatorname{csr} B$ mutants. Because the $c s r B$ mutant did not exhibit any notable defects in growth and virulence, increased expression of heat-shock genes in the $\operatorname{csr} B$ mutant appears to be caused by a different source of stress. Extrapolating from the function of heat-shock proteins, one possibility is that heat-shock gene expression might be induced in response to significantly increased levels of T3SS and flagellar proteins in the cell. Transcriptomic analysis in this study was performed when T3SS transcript levels reached a peak in the WT (Lee and Zhao 2018). The csrB mutant exhibited up to 11-fold upregulation of T3SS and flagellar proteins, and also up to 6-fold upregulation of proteins for amylovoran production, possibly resulting in sudden increased demand for molecular chaperones. Several studies have reported a similar induction pattern of heat-shock genes during overproduction of recombinant proteins in Escherichia coli to ensure correct protein folding (Hoffmann and Rinas 2000; Jürgen et al. 2000; Li et al. 2017). Upregulation of heat-shock genes in the $\operatorname{csr} B$ mutant might be also associated with the function of T3SS or flagellar motor. It was reported in E. coli that $\mathrm{HtpG}$ is required for the production of virulence-associated secondary metabolites (colibactin and yersiniabactin) and the activity of CRISPR/Cas system (Garcie et al. 2016; Yosef et al. 2011). HtpG of E. coli also can directly interact with cytoplasmic flagellar motor components FliN and FliI ( $\mathrm{Li}$ and Sourjik 2011). Moreover, heat-shock proteins in eukaryotes are widely observed in the assembly process of oligomers and protein complexes (Haslbeck and Vierling 2015), suggesting that bacterial heat-shock proteins might also be capable of promoting the assembly of T3SS or flagellar motor apparatus.

In addition, the tau and ssu gene clusters, encoding ABCtype sulfur transporters and sulfur metabolism-related products, were also upregulated in both $c s r A$ and $c s r B$ mutants. Expression of both gene clusters is reported to be positively regulated by the Cbl transcription factor in E. coli (van der Ploeg et al. 1997, 1999). In our transcriptomic data, the $c s r A$ mutant showed approximately 12 -fold increased expression of $c b l$ as compared with the WT and, accordingly, showed a significant upregulation of 13 sulfur metabolism genes known to contain Cbl-dependent promoter, including tauABCD, ssuEADC, cysK, cysHIJ, and $s b p$ (van der Ploeg et al. 2001). Other sulfur metabolism genes such as cys $P$ and $c y s C N D$ were also upregulated in the $c s r A$ mutant. It has been reported that sulfur metabolism is highly associated with methionine and cysteine biosynthesis as well as oxidative stress response (Gyaneshwar et al. 2005), further suggesting unstable intracellular states in the csrA mutant. However, no significant changes in transcript levels of $c b l$ and other sulfur metabolism genes were observed in the $\operatorname{csr} B$ mutant; thus, upregulation of the tau and $s s u$ genes might be mediated by yet-unknown regulatory factors, which are possibly associated with CsrA.

On the other hand, expression of 33 genes was negatively regulated by CsrA and, of these, the $r \operatorname{cs} V$ gene was the most strongly induced in the absence of CsrA. The $r c s V$ gene of Erwinia amylovora that was first identified can recover EPS production in the rcsA mutant of Pantoea stewartii (Aldridge et al. 1998). However, it was reported that the $r c s V$ mutant of E. amylovora caused no phenotypic differences, and its expression was not induced even under the strong lac promoter by unknown mechanism (Aldridge et al. 1998). Our transcriptomic analysis showed that $r c s V$ expression was highly enhanced in the $c s r A$ mutant but suppressed in the $c s r B$ mutant, suggesting that the Csr system might be responsible for the suppression of $r c s V$ expression under normal conditions. A gene cluster (EAMY_2813 to EAMY_2820), encoding Cas proteins, was also negatively regulated by CsrA. Consistent with its primary role as a defense mechanism against foreign nucleic acids, cas gene expression has been reported to be induced against viral infection and regulated by various transcription factors and signaling molecules (Patterson et al. 2017), whereas a role of the Csr system in the CRISPR/Cas system regulation was not reported. Because the CRISPR/Cas system utilizes guide RNAs to target invading genetic elements, it may also contribute to posttranscriptional regulation through the RNA interferencelike system (Bhaya et al. 2011). In E. amylovora, studies of the CRISPR/Cas system have been focused on genetic diversity of short DNA repeat sequences from different isolates (McGhee and Sundin 2012; Rezzonico et al. 2011); thus, our knowledge of its function and gene regulation is still incomplete. Further studies are warranted to assess interaction of the Csr system with the CRISPR/Cas system.

The nucleotide second messenger (p)ppGpp is another major global regulatory system in bacteria. Under starvation conditions, bacteria produce high levels of (p)ppGpp, which induces massive transcriptional reprogramming to adjust various stress responses (Dalebroux and Swanson 2012). During early stages of infection, E. amylovora undergoes the nutrient-limited conditions. The subsequent accumulation of (p)ppGpp plays an essential role in virulence activation by reducing cell size to increase resistance to abiotic stresses and activating the RpoN-HrpL alternative $\sigma$ factor cascade for T3SS gene expression (Ancona et al. 2015b; Khakimova et al. 2013). Because the presence of both (p)ppGpp and CsrA is essential for the T3SS, codependence of two global regulators was of particular interest in our studies. In Escherichia coli, (p)ppGpp and DksA positively regulate the expression of CsrA and $\operatorname{csr} B / \operatorname{csr} C$ sRNAs, while CsrA suppresses (p)ppGpp accumulation by inhibiting relA translation, forming a reciprocal regulatory circuit (Edwards et al. 2011). In contrast, in Erwinia amylovora, the absence in $d k s A$ resulted in approximately twofold decrease in $c s r A$ transcription but no significant effects by (p)ppGpp were observed on $\operatorname{csr} B$ expression under the T3SSinducing condition (unpublished data). E. amylovora CsrA is also required for efficient translation of relA, although it binds to the region near the ribosome-binding site and the start codon. Similar observations were reported in L. pneumophila but the exact molecular mechanisms underlying this auxiliary effect of CsrA binding remain unclear (Sahr et al. 2017). Taken together, CsrA might enable E. amylovora to induce higher levels of (p)ppGpp by maintaining a cellular nucleotide pool and also activating efficient relA translation.

The Rcs phosphorelay system is only found in enterobacterial pathogens and is well known as a regulator of EPS production and biofilm formation (Erickson and Detweiler 2006; Ferrières and Clarke 2003; Majdalani and Gottesman 2005). In E. amylovora, the Rcs system acts as an essential virulence regulator by activating $h r p S$ and amylovoran production, and also contributes to the regulation of motility, $\operatorname{csr} B$ expression, and antibiotic resistance (Ancona et al. 2015a; Ge et al. 2018; Lee et al. 2018; Wang et al. 2009, 2012). Given that RcsBdependent genes, including $\operatorname{hrp} S$ and $\operatorname{rcs} A$, were differentially expressed in the $\operatorname{csr} B$ mutant without changes in $r \operatorname{cs} B$ transcript level (Lee and Zhao 2018), we assumed that increased activity of CsrA might elevate the activity of the Rcs system. In E. amylovora, because $r c s B$ expression was stable in different conditions, phosphorylation status of RcsB was thought to be a major determinant of the Rcs system activity (Wang et al. 2012). However, our study showed that CsrA can directly interact with the leader sequence of $r \operatorname{cs} B$ and positively regulate its translation, proposing a novel mechanism that affects the Rcs system activity through posttranscriptional regulation.

In Escherichia coli, it is well established that CsrA binding of flhD inhibits RNase E-mediated cleavage and enhances its translation rate (Wei et al. 2001; Yakhnin et al. 2013). Consistently, CsrA of Erwinia amylovora also binds to multiple 
sites on the $f l h D$ transcript, resulting in enhanced translation. This finding reinforces our previous observations that mutant strains with increased CsrA activity such as the $\operatorname{csr} B, \operatorname{grrS} / \mathrm{grrA}$, and ihf mutants were hypermotile (Ancona et al. 2016; Lee and Zhao 2016; Li et al. 2014). Although it was not detected from the lac $Z$ reporter fusion assays under the flagellar geneinducing condition, transcriptome analysis under the T3SSinducing condition showed that flagellar class 3 genes (fliA, $f l g M$, and $f l i D)$ were approximately threefold upregulated as compared with flagellar class 2 genes $(f l i L$ and $f l i P$ ) in the $c s r B$ mutant. This might suggest that CsrA-dependent flagellar gene regulation could also be mediated through the class 3 gene regulators fliA and $f l g M$, which need further verification.

In summary, our research demonstrated that CsrA is a key component coordinating a number of cellular processes in E. amylovora, and its direct targets, including $\mathrm{FlhD}, \mathrm{RcsB}$, and RelA, are responsible for the regulation of virulence factors, including T3SS, amylovoran, and motility. However, our understanding of how the Csr system monitors cellular homeostasis is still incomplete. Future direction of this study might include identification of additional CsrA target genes that are associated with the regulation of physiologically important processes.

\section{MATERIALS AND METHODS}

\section{Bacterial strains and growth conditions.}

Bacterial strains and plasmids used in this study are listed in Table 3. Luria-Bertani (LB) was used routinely to culture
E. amylovora and Escherichia coli strains, and the HMM (1 $\mathrm{g}$ of $\left[\mathrm{NH}_{4}\right]_{2} \mathrm{SO}_{4}, 0.246 \mathrm{~g}$ of $\mathrm{MgCl}_{2} \cdot 6 \mathrm{H}_{2} \mathrm{O}, 0.1 \mathrm{~g}$ of $\mathrm{NaCl}, 8.708 \mathrm{~g}$ of $\mathrm{K}_{2} \mathrm{HPO}_{4}$, and $6.804 \mathrm{~g}$ of $\mathrm{KH}_{2} \mathrm{PO}_{4}$ ) supplemented with $10 \mathrm{mM}$ galactose as carbon source was used to determine gene expression (Ancona et al. 2014). TB (10 g of tryptone and $5 \mathrm{~g}$ of $\mathrm{NaCl}$ per 1 liter) was used to measure flagellar gene expression. When required, antibiotics were added at the following concentrations: ampicillin at $100 \mu \mathrm{g} / \mathrm{ml}$, kanamycin $(\mathrm{Km})$ at $50 \mu \mathrm{g} / \mathrm{ml}$, chloramphenicol at $10 \mu \mathrm{g} / \mathrm{ml}$, and gentamicin at $10 \mu \mathrm{g} / \mathrm{ml}$. Primers used in this study are listed in Supplementary Table S5.

\section{RNA isolation, RNA-seq, and qRT-PCR.}

RNA was isolated from cell cultures grown in HMM for $6 \mathrm{~h}$ at $18^{\circ} \mathrm{C}$ using the RNeasy minikit (Qiagen, Hilden, Germany), followed by DNase I treatment using the TURBO DNA-free kit (Thermo Fisher Scientific, Waltham, MA, U.S.A.), according to the manufacturer's instructions. The quantity and quality of RNA samples were assessed using either the Nano-Drop ND100 spectrophotometer (Nano-Drop Technologies, Wilmington, DE, U.S.A.) or Agilent RNA 6000 Nano Chip Bioanalyzer (Agilent, Santa Clara, CA, U.S.A.). For RNA-seq analysis, library construction and sequencing using Illumina HiSeq 2500 (Illumina, San Diego, CA, U.S.A.) were performed on three biological samples for the WT and the mutants by the Keck Center at the University of Illinois at Urbana-Champaign (UIUC). The sequence reads were aligned to the genome of Erwinia amylovora CFBP1430 (Smits et al. 2010) using Bowtie

Table 3. Bacterial strains and plasmids used in this study

\begin{tabular}{|c|c|c|}
\hline Strains, plasmids & Description $^{a}$ & Reference, source \\
\hline \multicolumn{3}{|l|}{ Erwinia amylovora } \\
\hline Ea1189 & Wild type, isolated from apple & Wang et al. 2009 \\
\hline$\Delta c s r A$ & $\operatorname{csr} A:: \mathrm{Cm} ; \mathrm{Cm}^{\mathrm{R}}$-insertional mutant of $\operatorname{csr} A$ of Ea1 189 & Ancona et al. 2016 \\
\hline$\Delta c s r B$ & $\operatorname{csr} B:: \mathrm{Cm} ; \mathrm{Cm}^{\mathrm{R}}$-insertional mutant of $c \operatorname{sr} B$ of Ea1 189 & Ancona et al. 2016 \\
\hline \multicolumn{3}{|l|}{ Escherichia coli } \\
\hline DH10B & 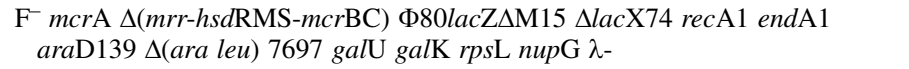 & Invitrogen \\
\hline BL21 (DE3) & $\mathrm{F}^{-} o m p T h s d S_{\mathrm{B}}\left(\mathrm{r}_{\mathrm{B}}^{-} \mathrm{m}_{\mathrm{B}}^{-}\right)$gal dcm (DE3) & Novagen \\
\hline XL10-Gold & $\begin{array}{l}\mathrm{Tet}^{\mathrm{R}} \Delta(\text { mcrA }) 183 \Delta(\text { mcrCB-hsdSMR-mrr }) 173 \text { endA1 supE44 thi-1 recA1 gyrA96 } \\
\quad \text { relA1 lac Hte }\end{array}$ & Stratagene \\
\hline \multicolumn{3}{|c|}{ ( } \\
\hline pWSK29 & $A p^{R}$, cloning vector, low copy number & Wang and Kushner 1991 \\
\hline pET28a & $\begin{array}{l}\mathrm{Km}^{\mathrm{R}} \text {, T7 expression vector carrying an } \mathrm{N} \text {-terminal His-Tag/thrombin/T7 Tag } \\
\text { configuration plus an optional C-terminal His-Tag sequence }\end{array}$ & Novagen \\
\hline pCsrA-His & 183-bp DNA fragment containing $c s r A$ gene in pET28a & This study \\
\hline pRS552 & Translation fusion vector containing the MCS, EcoRI-SmaI-BamHI-lacZYA' & Simons et al. 1987 \\
\hline pHRP309 & Broad-host-range lac $Z$ transcriptional fusion vector, $\mathrm{Gm}^{\mathrm{R}}$ & Parales and Harwood \\
\hline pZLac29 & pWSK29 containing the MCS, EcoRI-SmaI-BamHI-lacZ & This study \\
\hline pFlhD309 & 626-bp Fragment containing $f l h D$ gene $(-600-+26)$ in pHRP309 & This study \\
\hline pFliL309 & 626-bp Fragment containing fliL gene $(-600-+26)$ in pHRP309 & This study \\
\hline pFliA309 & 626-bp Fragment containing fliA gene $(-600-+26)$ in pHRP309 & This study \\
\hline pFlgM309 & 626-bp Fragment containing flgM gene $(-600-+26)$ in pHRP309 & This study \\
\hline pFliD309 & 626-bp Fragment containing fliD gene $(-600-+26)$ in pHRP309 & This study \\
\hline pFlhD29 & 626-bp Fragment containing $f l h D$ gene $(-600-+26)$ in pZLac29 & This study \\
\hline pFlhD29-Mut1 & $\begin{array}{l}\text { 626-bp Fragment containing } f l h D \text { gene }(-600-+26) \text { with a mutation at position } \\
-253 \text { to }-251 \text { in pZLac29 }\end{array}$ & This study \\
\hline pFlhD29-Mut2 & $\begin{array}{l}\text { 626-bp Fragment containing } f l h D \text { gene }(-600-+26) \text { with a mutation at position } \\
-216 \text { to }-214 \text { in pZLac29 }\end{array}$ & This study \\
\hline pFlhD29-Mut3 & $\begin{array}{l}\text { 626-bp Fragment containing } f l h D \text { gene }(-600-+26) \text { with a mutation at position } \\
-204 \text { to }-202 \text { in pZLac29 }\end{array}$ & This study \\
\hline pFlhD29-Mut4 & $\begin{array}{l}\text { 626-bp Fragment containing } f l h D \text { gene }(-600-+26) \text { with a mutation at position } \\
-189 \text { to }-187 \text { in pZLac29 }\end{array}$ & This study \\
\hline pRelA29 & 626-bp Fragment containing relA gene $(-600-+26)$ in pZLac29 & This study \\
\hline pRelA29-Mut & $\begin{array}{l}\text { 626-bp Fragment containing } f l h D \text { gene }(-600-+26) \text { with a mutation at position } \\
-20 \text { to }-18 \text { in pZLac } 29\end{array}$ & This study \\
\hline pSpoT29 & 626-bp Fragment containing spoT gene $(-600-+26)$ in pZLac29 & This study \\
\hline pResD29 & 626-bp Fragment containing $r c s D$ gene $(-600-+26)$ in pZLac29 & This study \\
\hline pResB29 & 626-bp Fragment containing $r c s B$ gene $(-600-+26)$ in pZLac29 & This study \\
\hline
\end{tabular}

${ }^{\mathrm{a}} \mathrm{Cm}=$ chloramphenicol; $\mathrm{Cm}^{\mathrm{R}}, \mathrm{Tet}^{\mathrm{R}}, \mathrm{Ap}^{\mathrm{R}}, \mathrm{Km}^{\mathrm{R}}$, and $\mathrm{Gm}^{\mathrm{R}}=$ resistant to chloramphenicol, tetracycline, ampicillin, kanamycin, and gentamicin, respectively. 
0.12.7 (Langmead et al. 2009). To perform normalization and statistical analysis on the raw read counts, the $\mathrm{R}$ package DESeq2 was used as described previously (Love et al. 2014). DEGs were defined as genes with a $\log _{2} \mathrm{FC}$ value $\geq 1$ and a corrected $P$ value $<0.05$ from three independent biological replicates. The RNA-seq data files have been submitted to Gene Expression Omnibus at the NCBI with an accession number GSE128088.

For qRT-PCR, reverse transcription was performed using Superscript III reverse transcription (Invitrogen, Carlsbad, CA, U.S.A.), and cDNA samples were mixed with Power SYBR Green PCR master mix (Applied Biosystems, CA, U.S.A.) and appropriate primers. The StepOnePlus Real-Time PCR system (Applied Biosystems) was used for qRT-PCR under the following conditions: $95^{\circ} \mathrm{C}$ for $10 \mathrm{~min}$, followed by 40 cycles of $95^{\circ} \mathrm{C}$ for $15 \mathrm{~s}$ and $60^{\circ} \mathrm{C}$ for $1 \mathrm{~min}$. Primer specificities were assessed using melting curves. The $r p o D$ gene was used as an endogenous control to calculate relative quantification $(\Delta \Delta C \mathrm{t})$. The experiment was repeated three times, and statistical analysis was performed using Student's $t$ test with $P<0.05$.

\section{CsrA protein purification.}

The coding sequence of the csrA gene was cloned into pET28a expression vector (Novagen, Madison, WI, U.S.A.) and, after confirmation by sequencing at the Keck center of UIUC, final plasmid was introduced into Escherichia coli strain BL21 (DE3). Overnight culture of the CsrA-overexpressing strain was inoculated into $500 \mathrm{ml}$ of fresh LB media containing $\mathrm{Km}$ at $50 \mu \mathrm{g} / \mathrm{ml}$. After 2 to $3 \mathrm{~h}$ of growth, bacteria culture was treated with $0.1 \mathrm{mM}$ isopropyl- $\beta$-D-thiogalactoside to induce protein expression and incubated overnight at $18^{\circ} \mathrm{C}$. Cells were harvested, washed with cell wash buffer $(50 \mathrm{mM}$ morpholinepropanesulfonic acid [MOPS] and $150 \mathrm{mM} \mathrm{NaCl}$ ), and resuspended (1:10 ratio [wt/vol]) in cell wash buffer. Cell suspension was treated with lysozyme (Promega Corp., Madison, WI, U.S.A.) at $250 \mu \mathrm{g} / \mathrm{ml}$ for $30 \mathrm{~min}$, cooled on ice for $30 \mathrm{~min}$, and mixed with $1 \times$ Halt protease inhibitor (Thermo Fisher Scientific), $\mathrm{NaCl}(300 \mathrm{mM})$, and imidazole $(60 \mathrm{mM})$. After sonication, cell lysates were removed by centrifugation at $35,000 \times g$ for $20 \mathrm{~min}$. The supernatant was treated with Ni-NTA agarose resin (Qiagen) at $4^{\circ} \mathrm{C}$ for $30 \mathrm{~min}$ with gentle rocking to collect His-tagged CsrA proteins. Ni-NTA resins were then washed with equilibration or wash buffer (50 mM MOPS, $300 \mathrm{mM}$ $\mathrm{NaCl}$, and $60 \mathrm{mM}$ imidazole), and proteins were eluted with elution buffer (50 mM MOPS, $300 \mathrm{mM} \mathrm{NaCl}$, and $500 \mathrm{mM}$ imidazole). Proteins were dialyzed overnight against buffer containing $20 \mathrm{mM}$ MOPS and $1 \mathrm{mM}$ dithiothreitol, and protein concentration was measured using Invitrogen Qubit protein assay.

\section{REMSA.}

Leader sequences of genes of interest were transcribed in vitro using the MEGAshortscript kit (Thermo Fisher Scientific) and labeled with biotin using the Pierce RNA $3^{\prime}$ end biotinylation kit (Thermo Fisher Scientific), according to the manufacturer's instructions. Reaction mixtures were prepared using the Lightshift chemiluminescent RNA EMSA kit (Thermo Fisher Scientific) in volumes of $10 \mu$, containing $2 \mathrm{nM}$ biotin-labeled target RNA, different amounts of CsrA protein, $1 \times$ binding buffer, $5 \%$ glycerol, and $0.4 \mathrm{U}$ of RNase inhibitor, incubated at room temperature for $20 \mathrm{~min}$, and mixed with $5 \times$ loading buffer. For competition assays, $2 \mathrm{nM}$ unlabeled $\operatorname{csr} B$ RNA was additionally added to the reaction mixture. CsrA-RNA complexes were separated on a $6 \%$ native polyacrylamide gel in $0.5 \times$ Tris-borate-EDTA buffer $(44.5 \mathrm{mM}$ Tris-base, $44.5 \mathrm{mM}$ boric acid, and $1 \mathrm{mM}$ EDTA), followed by UV-light crosslinking to a positively charged nylon membrane. Chemiluminescent signals were then detected using the ImageQuant LAS 4010 CCD camera (GE Healthcare, Piscataway, NJ, U.S.A.).

\section{$\beta$-Galactosidase assay.}

A $\beta$-galactosidase assay was performed using a microtiter plate, as described previously (Slauch and Silhavy 1991). Cell cultures grown in HMM for $6 \mathrm{~h}$ at $18^{\circ} \mathrm{C}$ were collected and resuspended in Z-buffer (Miller 1972). After measuring optical density at $600 \mathrm{~nm}\left(\mathrm{OD}_{600}\right)$, cell suspensions were treated with $1 \%$ sodium dodecyl sulfate and chloroform, then mixed with $o$-nitrophenyl galactoside (ONPG) at $10 \mathrm{mg} / \mathrm{ml}$ to initiate the reaction. Units for $\beta$-galactosidase assay are defined as (micromoles of ONP formed per minute $) \times 10^{6} /\left(\mathrm{OD}_{600} \times\right.$ milliliter of cell suspension) and reported as mean \pm standard deviation. Constructs of transcriptional and translational fusions were generated using vector pHRP309 and pZLac29, respectively, and confirmed by sequencing at the Keck center at UIUC. The vector pZLac 29 was generated by transferring multiple cloning sites and lacZ reporter genes from pRS552 into pWSK29. The assay was repeated three times, and statistical analysis was performed using Student's $t$ test with $P<0.05$.

\section{LITERATURE CITED}

Aldridge, P., Bernhard, F., Bugert, P., Coplin, D. L., and Geider, K. 1998. Characterization of a gene locus from Erwinia amylovora with regulatory functions in exopolysaccharide synthesis of Erwinia spp. Can. J. Microbiol. 44:657-666.

Ali Azam, T., Iwata, A., Nishimura, A., Ueda, S., and Ishihama, A. 1999. Growth phase-dependent variation in protein composition of the Escherichia coli nucleoid. J. Bacteriol. 181:6361-6370.

Ancona, V., Chatnaparat, T., and Zhao, Y. 2015a. Conserved aspartate and lysine residues of $\mathrm{RcsB}$ are required for amylovoran biosynthesis, virulence, and DNA binding in Erwinia amylovora. Mol. Genet. Genomics 290:1265-1276.

Ancona, V., Lee, J. H., Chatnaparat, T., Oh, J., Hong, J. I., and Zhao, Y. 2015b. The bacterial alarmone (p)ppGpp activates the type III secretion system in Erwinia amylovora. J. Bacteriol. 197:1433-1443.

Ancona, V., Lee, J. H., and Zhao, Y. 2016. The RNA-binding protein CsrA plays a central role in positively regulating virulence factors in Erwinia amylovora. Sci. Rep. 6: Article 37195.

Ancona, V., Li, W., and Zhao, Y. 2014. Alternative sigma factor RpoN and its modulation protein $\mathrm{YhbH}$ are indispensable for Erwinia amylovora virulence. Mol. Plant Pathol. 15:58-66.

Andrade, M. O., Farah, C. S., and Wang, N. 2014. The post-transcriptional regulator $r s m A / c s r A$ activates T3SS by stabilizing the $5^{\prime} \mathrm{UTR}$ of $h r p G$, the master regulator of $h r p / h r c$ genes, in Xanthomonas. PLoS Pathog. 10: e1003945.

Babitzke, P., and Romeo, T. 2007. CsrB sRNA family: Sequestration of RNA-binding regulatory proteins. Curr. Opin. Microbiol. 10:156-163.

Bernhard, F., Coplin, D. L., and Geider, K. 1993. A gene cluster for amylovoran synthesis in Erwinia amylovora: Characterization and relationship to cps genes in Erwinia stewartii. Mol. Gen. Genet. 239: 158-168.

Bhaya, D., Davison, M., and Barrangou, R. 2011. CRISPR-Cas systems in bacteria and archaea: Versatile small RNAs for adaptive defense and regulation. Annu. Rev. Genet. 45:273-297.

Burrowes, E., Baysse, C., Adams, C., and O'Gara, F. 2006. Influence of the regulatory protein RsmA on cellular functions in Pseudomonas aeruginosa PAO1, as revealed by transcriptome analysis. Microbiology $152: 405-418$

Büttner, D. 2012. Protein export according to schedule: Architecture, assembly, and regulation of type III secretion systems from plant- and animal-pathogenic bacteria. Microbiol. Mol. Biol. Rev. 76:262-310.

Dalebroux, Z. D., and Swanson, M. S. 2012. ppGpp: Magic beyond RNA polymerase. Nat. Rev. Microbiol. 10:203-212.

Dillon, S. C., and Dorman, C. J. 2010. Bacterial nucleoid-associated proteins, nucleoid structure and gene expression. Nat. Rev. Microbiol. 8: 185-195.

Dugar, G., Svensson, S. L., Bischler, T., Wäldchen, S., Reinhardt, R., Sauer, M., and Sharma, C. M. 2016. The CsrA-FliW network controls polar localization of the dual-function flagellin mRNA in Campylobacter jejuni. Nat. Commun. 7: Article 11667. 
Edwards, A. N., Patterson-Fortin, L. M., Vakulskas, C. A., Mercante, J. W., Potrykus, K., Vinella, D., Camacho, M. I., Fields, J. A., Thompson, S. A., Georgellis, D., Cashel, M., Babitzke, P., and Romeo, T. 2011. Circuitry linking the $\mathrm{Csr}$ and stringent response global regulatory systems. Mol. Microbiol. 80:1561-1580.

Erickson, K. D., and Detweiler, C. S. 2006. The Rcs phosphorelay system is specific to enteric pathogens/commensals and activates ydeI, a gene important for persistent Salmonella infection of mice. Mol. Microbiol. 62:883-894.

Ferrières, L., and Clarke, D. J. 2003. The RcsC sensor kinase is required for normal biofilm formation in Escherichia coli $\mathrm{K}-12$ and controls the expression of a regulon in response to growth on a solid surface. Mol. Microbiol. 50:1665-1682.

Figueroa-Bossi, N., Schwartz, A., Guillemardet, B., D’Heygère, F., Bossi, L., and Boudvillain, M. 2014. RNA remodeling by bacterial global regulator CsrA promotes Rho-dependent transcription termination. Genes Dev. 28:1239-1251.

Garcie, C., Tronnet, S., Garénaux, A., McCarthy, A. J., Brachmann, A. O., Pénary, M., Houle, S., Nougayrède, J. P., Piel, J., Taylor, P. W., Dozois, C. M., Genevaux, P., Oswald, E., and Martin, P. 2016. The bacterial stress-responsive Hsp90 chaperone (htpG) is required for the production of the genotoxin colibactin and the siderophore yersiniabactin in Escherichia coli. J. Infect. Dis. 214:916-924.

Ge, Y., Lee, J. H., Hu, B., and Zhao, Y. 2018. Loss-of-function mutations in the Dpp and Opp permeases render Erwinia amylovora resistant to kasugamycin and blasticidin S. Mol. Plant-Microbe Interact. 31: 823-832.

Gyaneshwar, P., Paliy, O., McAuliffe, J., Popham, D. L., Jordan, M. I., and Kustu, S. 2005. Sulfur and nitrogen limitation in Escherichia coli K-12: Specific homeostatic responses. J. Bacteriol. 187:1074-1090.

Haslbeck, M., and Vierling, E. 2015. A first line of stress defense: Small heat shock proteins and their function in protein homeostasis. J. Mol. Biol. 427:1537-1548.

Hoffmann, F., and Rinas, U. 2000. Kinetics of heat-shock response and inclusion body formation during temperature-induced production of basic fibroblast growth factor in high-cell-density cultures of recombinant Escherichia coli. Biotechnol. Prog. 16:1000-1007.

Holmqvist, E., Wright, P. R., Li, L., Bischler, T., Barquist, L., Reinhardt, R., Backofen, R., and Vogel, J. 2016. Global RNA recognition patterns of post-transcriptional regulators $\mathrm{Hfq}$ and CsrA revealed by UV crosslinking in vivo. EMBO J. 35:991-1011.

Jürgen, B., Lin, H. Y., Riemschneider, S., Scharf, C., Neubauer, P., Schmid, R., Hecker, M., and Schweder, T. 2000. Monitoring of genes that respond to overproduction of an insoluble recombinant protein in Escherichia coli glucose-limited fed-batch fermentations. Biotechnol. Bioeng. 70:217-224.

Khakimova, M., Ahlgren, H. G., Harrison, J. J., English, A. M., and Nguyen, D. 2013. The stringent response controls catalases in Pseudomonas aeruginosa and is required for hydrogen peroxide and antibiotic tolerance. J. Bacteriol. 195:2011-2020.

Khan, M. A., Zhao, Y. F., and Korban, S. S. 2012. Molecular mechanisms of pathogenesis and resistance to the bacterial pathogen Erwinia amylovora, causal agent of fire blight disease in Rosaceae. Plant Mol. Biol. Rep. 30:247-260.

Koczan, J. M., McGrath, M. J., Zhao, Y., and Sundin, G. W. 2009. Contribution of Erwinia amylovora exopolysaccharides amylovoran and levan to biofilm formation: Implications in pathogenicity. Phytopathology 99:1237-1244.

Langmead, B., Trapnell, C., Pop, M., and Salzberg, S. L. 2009. Ultrafast and memory-efficient alignment of short DNA sequences to the human genome. Genome Biol. 10:R25.

Lawhon, S. D., Frye, J. G., Suyemoto, M., Porwollik, S., McClelland, M., and Altier, C. 2003. Global regulation by CsrA in Salmonella typhimurium. Mol. Microbiol. 48:1633-1645.

Lee, J. H., Ancona, V., and Zhao, Y. 2018. Lon protease modulates virulence traits in Erwinia amylovora by direct monitoring of major regulators and indirectly through the Rcs and Gac-Csr regulatory systems. Mol. Plant Pathol. 19:827-840.

Lee, J. H., Sundin, G. W., and Zhao, Y. 2016. Identification of the HrpS binding site in the $h r p L$ promoter and effect of the RpoN binding site of HrpS on the regulation of the type III secretion system in Erwinia amylovora. Mol. Plant Pathol. 17:691-702.

Lee, J. H., and Zhao, Y. 2016. Integration host factor is required for RpoNdependent $h r p L$ gene expression and controls motility by positively regulating rsmB sRNA in Erwinia amylovora. Phytopathology 106: 29-36.

Lee, J. H., and Zhao, Y. 2018. Integration of multiple stimuli-sensing systems to regulate $\mathrm{HrpS}$ and type III secretion system in Erwinia amylovora. Mol. Genet. Genomics 293:187-196.
Li, H., and Sourjik, V. 2011. Assembly and stability of flagellar motor in Escherichia coli. Mol. Microbiol. 80:886-899.

Li, W., Ancona, V., and Zhao, Y. 2014. Co-regulation of polysaccharide production, motility, and expression of type III secretion genes by EnvZ/OmpR and GrrS/GrrA systems in Erwinia amylovora. Mol. Genet. Genomics 289:63-75.

Li, Z., Nimtz, M., and Rinas, U. 2017. Global proteome response of Escherichia coli BL21 to production of human basic fibroblast growth factor in complex and defined medium. Eng. Life Sci. 17:881-891.

Love, M. I., Huber, W., and Anders, S. 2014. Moderated estimation of fold change and dispersion for RNA-seq data with DESeq2. Genome Biol. 15:550.

Majdalani, N., and Gottesman, S. 2005. The Res phosphorelay: A complex signal transduction system. Annu. Rev. Microbiol. 59:379-405.

Martínez, L. C., Yakhnin, H., Camacho, M. I., Georgellis, D., Babitzke, P., Puente, J. L., and Bustamante, V. H. 2011. Integration of a complex regulatory cascade involving the SirA/BarA and Csr global regulatory systems that controls expression of the Salmonella SPI-1 and SPI-2 virulence regulons through HilD. Mol. Microbiol. 80: 1637-1656.

McGhee, G. C., and Sundin, G. W. 2012. Erwinia amylovora CRISPR elements provide new tools for evaluating strain diversity and for microbial source tracking. PLoS One 7:e41706.

McNally, R. R., Toth, I. K., Cock, P. J. A., Pritchard, L., Hedley, P. E., Morris, J. A., Zhao, Y., and Sundin, G. W. 2012. Genetic characterization of the HrpL regulon of the fire blight pathogen Erwinia amylovora reveals novel virulence factors. Mol. Plant Pathol. 13:160-173.

Miller, J. H. 1972. Assay of $\beta$-galactosidase. Pages 352-355 in: Experiments in Molecular Genetics. CSH Laboratory Press, Cold Spring Harbor, NY, U.S.A.

Morimoto, R. I. 1993. Cells in stress: Transcriptional activation of heat shock genes. Science 259:1409-1410.

Murata, M., Fujimoto, H., Nishimura, K., Charoensuk, K., Nagamitsu, H., Raina, S., Kosaka, T., Oshima, T., Ogasawara, N., and Yamada, M. 2011. Molecular strategy for survival at a critical high temperature in Escherichia coli. PLoS One 6:e20063.

Nimtz, M., Mort, A., Domke, T., Wray, V., Zhang, Y., Qiu, F., Coplin, D., and Geider, K. 1996. Structure of amylovoran, the capsular exopolysaccharide from the fire blight pathogen Erwinia amylovora. Carbohydr. Res. 287:59-76.

Patterson, A. G., Yevstigneyeva, M. S., and Fineran, P. C. 2017. Regulation of CRISPR-Cas adaptive immune systems. Curr. Opin. Microbiol. 37: 1-7.

Patterson-Fortin, L. M., Vakulskas, C. A., Yakhnin, H., Babitzke, P., and Romeo, T. 2013. Dual posttranscriptional regulation via a cofactorresponsive mRNA leader. J. Mol. Biol. 425:3662-3677.

Potts, A. H., Vakulskas, C. A., Pannuri, A., Yakhnin, H., Babitzke, P., and Romeo, T. 2017. Global role of the bacterial post-transcriptional regulator CsrA revealed by integrated transcriptomics. Nat. Commun. 8: Article 1596.

Rezzonico, F., Smits, T. H., and Duffy, B. 2011. Diversity, evolution, and functionality of clustered regularly interspaced short palindromic repeat (CRISPR) regions in the fire blight pathogen Erwinia amylovora. Appl. Environ. Microbiol. 77:3819-3829.

Sahr, T., Rusniok, C., Impens, F., Oliva, G., Sismeiro, O., Coppée, J. Y., and Buchrieser, C. 2017. The Legionella pneumophila genome evolved to accommodate multiple regulatory mechanisms controlled by the CsrAsystem. PLoS Genet. 13:e1006629.

Simons, R. W., Houman, F., and Kleckner, N. 1987. Improved single and multicopy lac-based cloning vectors for protein and operon fusions. Gene 53:85-96.

Slauch, J. M., and Silhavy, T. J. 1991. cis-acting ompF mutations that result in OmpR-dependent constitutive expression. J. Bacteriol. 173: 4039-4048.

Smits, T. H. M., Rezzonico, F., Kamber, T., Blom, J., Goesmann, A., Frey, J. E., and Duffy, B. 2010. Complete genome sequence of the fire blight pathogen Erwinia amylovora CFBP 1430 and comparison to other Erwinia spp. Mol. Plant-Microbe Interact. 23:384-393.

Suzuki, K., Babitzke, P., Kushner, S. R., and Romeo, T. 2006. Identification of a novel regulatory protein $(\mathrm{CsrD})$ that targets the global regulatory RNAs CsrB and CsrC for degradation by RNase E. Genes Dev. 20: 2605-2617.

Suzuki, K., Wang, X., Weilbacher, T., Pernestig, A. K., Melefors, O., Georgellis, D., Babitzke, P., and Romeo, T. 2002. Regulatory circuitry of the CsrA/CsrB and BarA/UvrY systems of Escherichia coli. J. Bacteriol. 184:5130-5140.

Vakulskas, C. A., Pannuri, A., Cortés-Selva, D., Zere, T. R., Ahmer, B. M., Babitzke, P., and Romeo, T. 2014. Global effects of the DEAD-box RNA 
helicase DeaD (CsdA) on gene expression over a broad range of temperatures. Mol. Microbiol. 92:945-958.

Vakulskas, C. A., Potts, A. H., Babitzke, P., Ahmer, B. M., and Romeo, T. 2015. Regulation of bacterial virulence by Csr (Rsm) systems. Microbiol. Mol. Biol. Rev. 79:193-224.

van der Ploeg, J. R., Eichhorn, E., and Leisinger, T. 2001. Sulfonate-sulfur metabolism and its regulation in Escherichia coli. Arch. Microbiol. 176:1-8.

van der Ploeg, J. R., Iwanicka-Nowicka, R., Bykowski, T., Hryniewicz, M. M., and Leisinger, T. 1999. The Escherichia coli ssuEADCB gene cluster is required for the utilization of sulfur from aliphatic sulfonates and is regulated by the transcriptional activator Cbl. J. Biol. Chem. 274 29358-29365.

van der Ploeg, J. R., Iwanicka-Nowicka, R., Kertesz, M. A., Leisinger, T., and Hryniewicz, M. M. 1997. Involvement of CysB and Cbl regulatory proteins in expression of the tauABCD operon and other sulfate starvationinducible genes in Escherichia coli. J. Bacteriol. 179:7671-7678.

Wang, D., Korban, S. S., and Zhao, Y. 2009. The Rcs phosphorelay system is essential for pathogenicity in Erwinia amylovora. Mol. Plant Pathol. 10:277-290.

Wang, D., Qi, M., Calla, B., Korban, S. S., Clough, S. J., Cock, P. J., Sundin, G. W., Toth, I., and Zhao, Y. 2012. Genome-wide identification of genes regulated by the Rcs phosphorelay system in Erwinia amylovora. Mol. Plant-Microbe Interact. 25:6-17.

Wang, R. F., and Kushner, S. R. 1991. Construction of versatile lowcopy-number vectors for cloning, sequencing and gene expression in Escherichia coli. Gene 100:195-199.
Wei, B. L., Brun-Zinkernagel, A. M., Simecka, J. W., Prüss, B. M., Babitzke, P., and Romeo, T. 2001. Positive regulation of motility and flhDC expression by the RNA-binding protein CsrA of Escherichia coli. Mol. Microbiol. 40:245-256

Wei, Z. M., and Beer, S. V. 1995. hrpL activates Erwinia amylovora hrp gene transcription and is a member of the ECF subfamily of sigma factors. J. Bacteriol. 177:6201-6210.

Yakhnin, A. V., Baker, C. S., Vakulskas, C. A., Yakhnin, H., Berezin, I. Romeo, T., and Babitzke, P. 2013. CsrA activates flhDC expression by protecting flhDC mRNA from RNase E-mediated cleavage. Mol Microbiol. 87:851-866.

Yosef, I., Goren, M. G., Kiro, R., Edgar, R., and Qimron, U. 2011. Hightemperature protein $\mathrm{G}$ is essential for activity of the Escherichia coli clustered regularly interspaced short palindromic repeats (CRISPR)/Cas system. Proc. Natl. Acad. Sci. U.S.A. 108:20136-20141.

Zere, T. R., Vakulskas, C. A., Leng, Y., Pannuri, A., Potts, A. H., Dias, R., Tang, D., Kolaczkowski, B., Georgellis, D., Ahmer, B. M., and Romeo, T. 2015. Genomic targets and features of BarA-UvrY (-SirA) signal transduction systems. PLoS One 10:e0145035.

Zhao, Y. 2014. Genomics of Erwinia amylovora and related species associated with pome fruit trees. Pages 1-36 in: Genomics of PlantAssociated Bacteria. D. Gross, A. Lichens-Park, and C. Kole, eds. Springer-Verlag, Berlin, Germany.

Zhao, Y., Sundin, G. W., and Wang, D. 2009. Construction and analysis of pathogenicity island deletion mutants of Erwinia amylovora. Can. J. Microbiol. 55:457-464. 